\begin{tabular}{c}
$\begin{array}{c}\text { Organization } \\
\text { for Educational } \\
\text { Research } \\
\text { and Planning }\end{array}$ \\
\hline
\end{tabular}

\title{
A Review of the Content of the Quran Textbooks for the Junior High School Based on the Parameters of Islamic Approach in Moral Education"
}

\begin{abstract}
-Shima Attar ${ }^{1}$ - Faezeh Nateghi ${ }^{2}$ - Nasrolah Erfani ${ }^{3}$
- Objective: The present study was conducted to identify the parameters of the Islamic approach in moral education and analyze the content of the Quran textbooks in the junior high school based on those parameters.

- Method: This study was conducted with a combination of library, Fuzzy Delphi, and Qualitative-Deductive Content Analysis Methods. In the library studies section, the research community consisted of scientific resources related to the research topic and the sampling method was available, which continued until the information saturation. The card repertoire was used to collect data and a qualitative method was used to analyze the data. In the Fuzzy Delphi section, the statistical population included professors working in universities of Hamadan Province in 1399 SH in the Fields of /educational science, psychology, and theology, 40 of whom were purposefully selected as a statistical sample. A researcher-made questionnaire was developed to collect data and the parameters of descriptive statistics were used to analyze the data. In the content analysis section, the statistical population consisted of the Quran textbooks for the junior high school, which were examined by the census method. A researcher-made content analysis checklist was used to collect the data and Shannon Entropy method was used to analyze the data.

- Findings: The findings indicate an unbalanced distribution of parameters of Islamic approach in moral education in the content of the abovementioned books, in a way that the highest coefficient of importance is related to the Index of enjoining good and the lowest coefficient of importance is related to the indices of attention to innate human tendencies, self-improvement and self-actualization, self-knowledge, conscious choice and voluntary action.

- Conclusion: it is necessary to review the content of the abovementioned books based on the characteristics of the Islamic approach in moral education.
\end{abstract}

\section{Keywords: Moral Education, Islamic Approach, Quran Textbook, Junior High School.}

n Citation: Shima Attar, Faezeh Nateghi, Nasrolah Erfani.(2021). A Review of the Content of the Quran Textbooks for the Junior High School Based on the Parameters of Islamic Approach in Moral Education, Applied Issues in Islamic education, 6(2): 87-108.

Received: $2020 / 02 / 20$

Accepted: $2021 / 05 / 21$

* This article is based on a Ph.D. Dissertation in Curriculum Planning in Arak Islamic Azad University, entitled «Reviewing The Position of Moral Education Approaches in Junior High School Curriculum and Presenting a Desirable Model».

1. APh.D. Student, Department of Educational Sciences, Arak Branch, Islamic Azad University, Arak, Iran E-mail: attar.sh2020@gmail.com. (DD 0000-0003-1110-0368

2. Corresponding Author: An Associate Professor, Department of Educational Sciences, Arak Branch, Islamic Azad University, Arak, Iran.

E-mail: f-nateghi@iau-arak.ac.ir. (iD 0000-0001-9465-0968

3. Associate Professor in Department of Psychology, Payame Noor University, Tehran, Iran. E-mail: erfani@pnu.ac.ir. (iD 0000-0002-6321-8491 



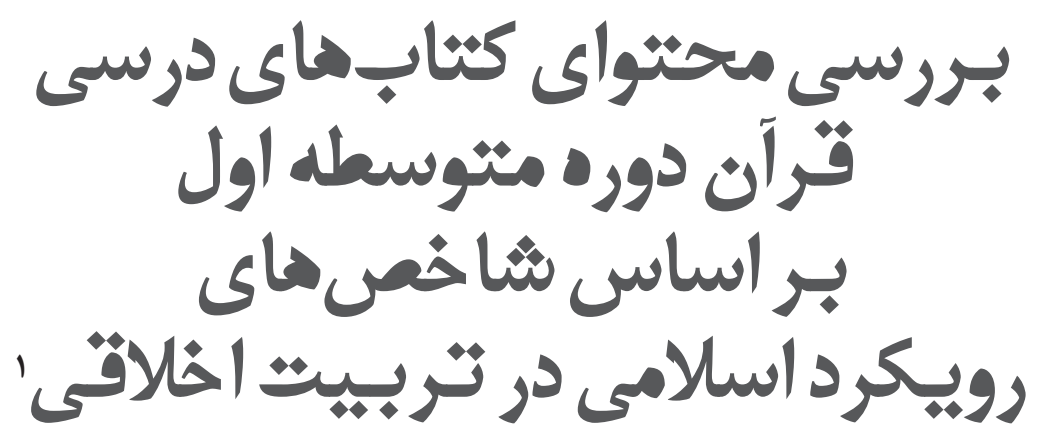

نصر اله عرفانى

"فائزه ناطقى

" شيما عطار

Qـ

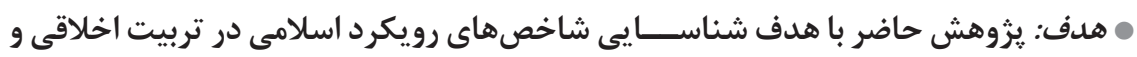

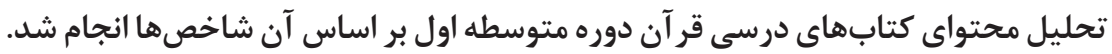
• روش: اين :يزوهش با تركيبى از روشهاى مطالعات كتابخانهاى، دلفى فازى، تحليل محتواى

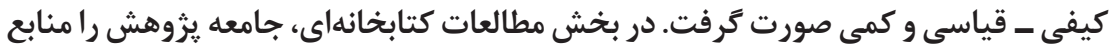

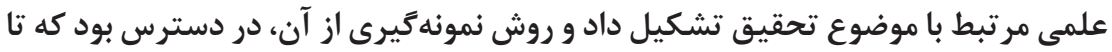

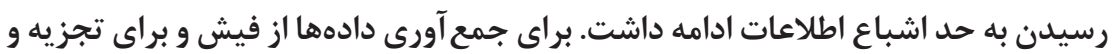

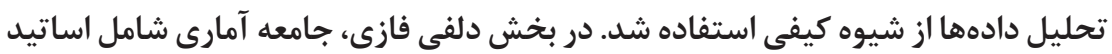

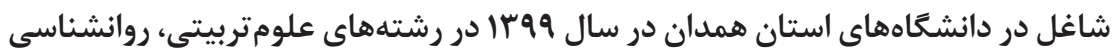

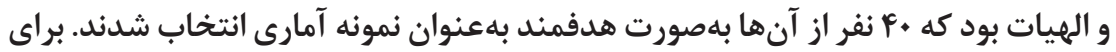

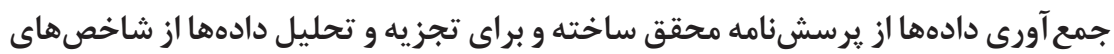

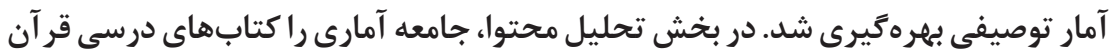

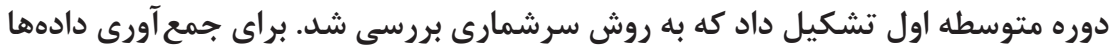
P

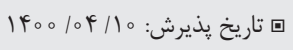

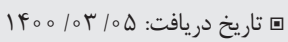

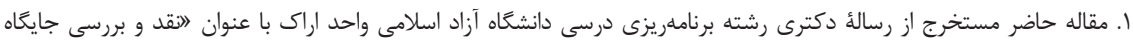

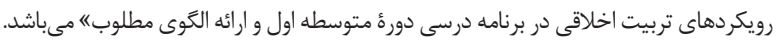

* * دانشجوى دكترى كروه علوم تربيتى، واحد اراك، دانشعاه آزاد اسلامى، اراك، ايران. E-mail: attar.sh2020@gmail.co. (D) 0000-0003-1110-0368

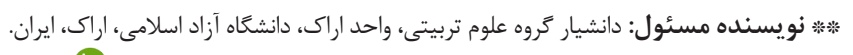
E-mail: f-nateghi@iau-arak.ac.ir. (D) orcid.org/0000-0001-9465-0968

E-mail: erfani@pnu.ac.ir. (D 0000-0002-6321-8491

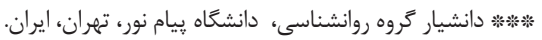


از جـى ليست محقق ساخته تحليل محتواو براى تجزيه و تحليل دادهها از روش آنترويى شانون بهرهبردارى كرديد.

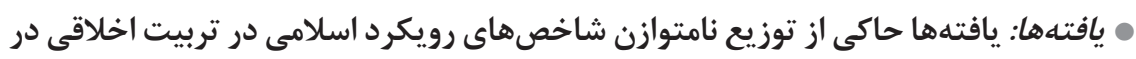

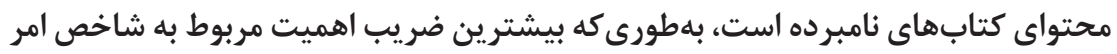

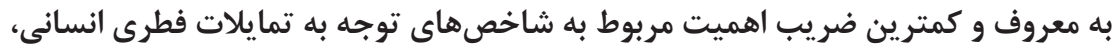

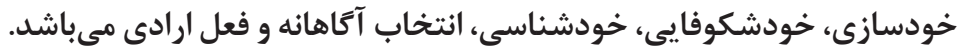
هنتيجهكيرى: بازنگرى در محتواى كتابهاى مذكور بر اساس شاخصهاى حوسى رويكرد اسلامى در تربيت اخلاقى ضرورى است. نتيجن.

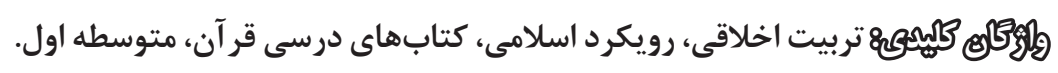

\section{مڤندم}

مقوله تربيت اخلاقى' به دليل نقش به سزايى كه در تنظيم امور زندگى انسان دارد، همواره مورد توجه فلاســفه، انديشمندان، متفكران اجتماعى و علماى اخلاق بوده است

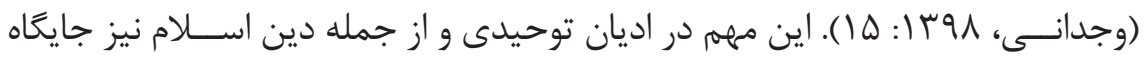

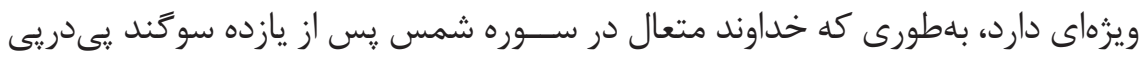

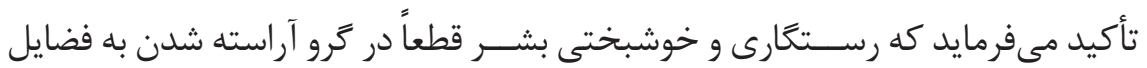
اخلاقى اســت (ســـوره شــمس: آيه 9). بنا بر آيات قرآن كريهم (مانند آلعمران: ع وع) و همجنين روايات متعدد از رســـول اكرم (ص) و ائمه اطهار(ع) تربيت اخلاقى بزرَترين هدف بعثت يُيامبران بوده اســت. بر همين اســاس، دين مبين اسلام با ارائه غنىترين معارف الهى، صاحب كســتردهترين نظام اخلاقى و به تبع آن، تربيت اخلاقى اســت. از سوى ديگر با تمركز بر برنامه تربيت اخلاقى رويكرد اسلامى مىتوان بيان داشت كه در نظام اخلاقى اســلام، تكاليف و الزامهاى اخلاقى، مسبوق به غايتى است كه همان كمال مطلوب انســان مىباشـــد و با راده، اختيار و انتخاب همراه هستند (حقيقت و مزيدى،

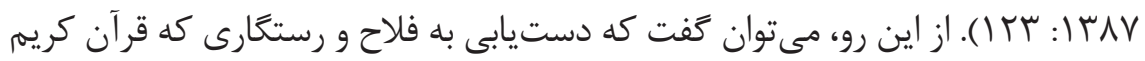
آن را بهعنوان مطلوب و غايت نهايى افعال اختيارى آدمى معرفى مى كند، تنها در سايه

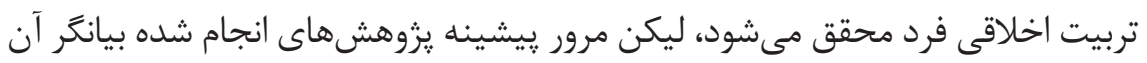


است كه با وجود تأكيد تعاليم اسلامى بر مفاهيه بنيادى و اساسى، براى اخلاق و يرورش

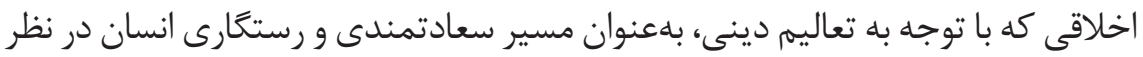

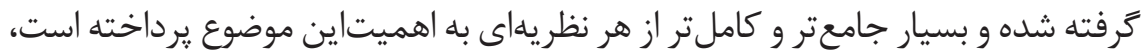
هنـــوز فرصتهاى يادكيرى كاربردى در خارجوب برنامه درســى براى يرداختن به اين

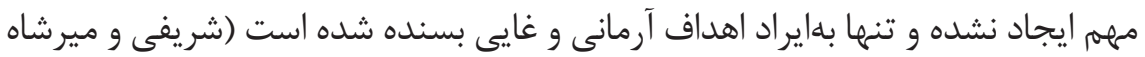

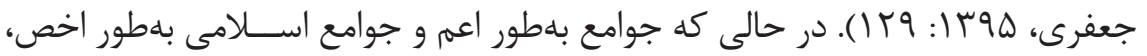

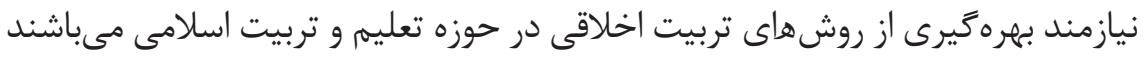

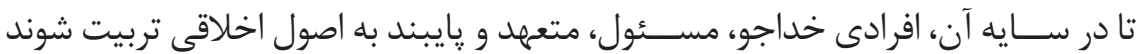

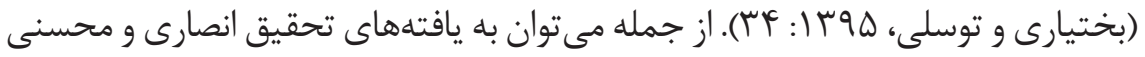

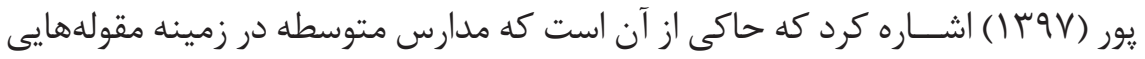
جون هويت دينى و بسترسازى رشد اخلاقى داراى عملكرد ضعيف مى باشند. يا مى تونان

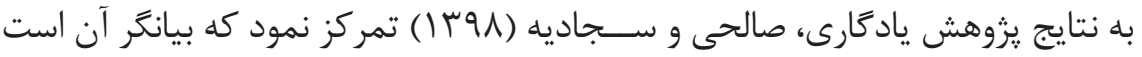

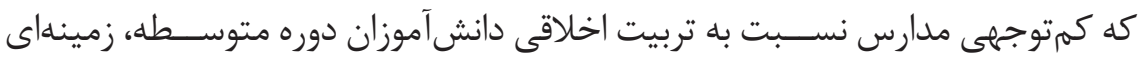

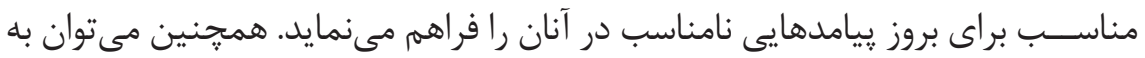

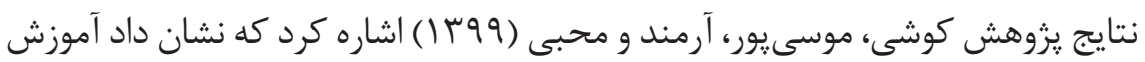

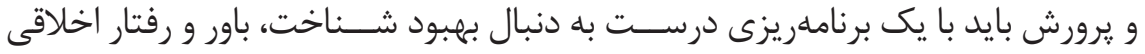

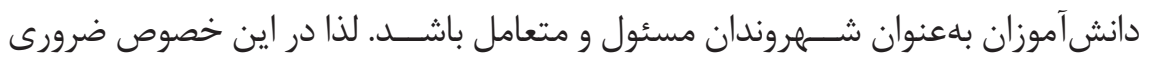

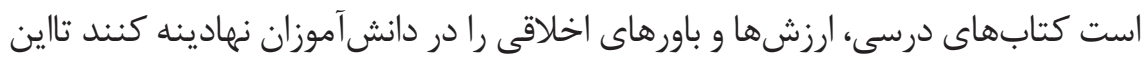

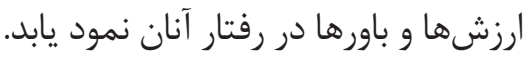

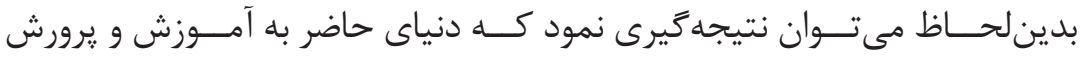

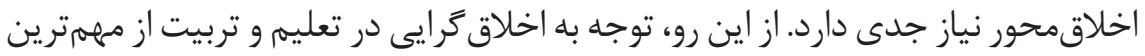
توصيهها و نكَرانىهاى آموزش و يرورش در هر كشورى است (جملنزاد و ذاكرى، هوسبا:

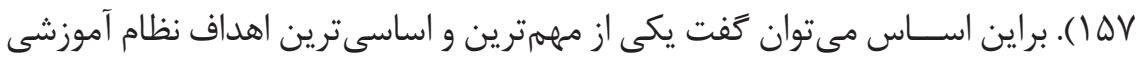

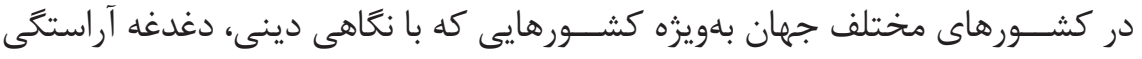

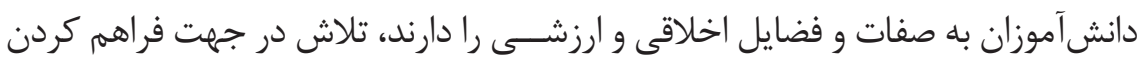

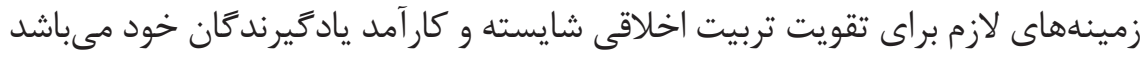




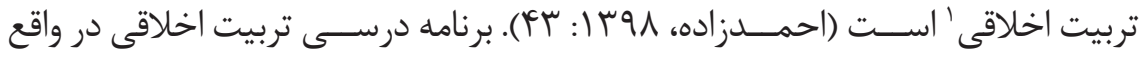
منظومهاى است كه در آن رويكرد كلى برنامه درسى اخلاق و عناصر وابسته به آن بهطور صحيح مشـــص مى گردد و ســازو گَارى اين عناصر با رويكرد و فرهنَ حاكم بر نظام

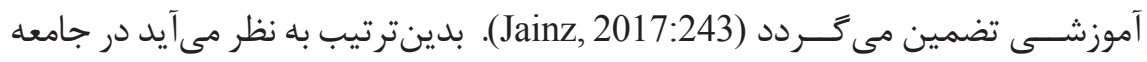

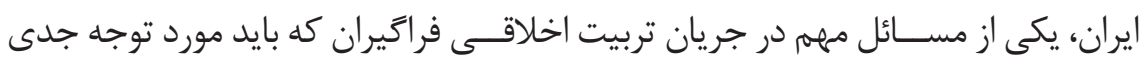
سياست كذاران، متوليان تربيتى، برنامهريزان درسى و مولفين كتابهاى درسى قرار گيرد، تمركز بر رويكرد اسلامى در تربيت اخلاقى است كه بهعنوان راهكارى مكمل براى كسب موفقيت در مسير جريان تربيت اخلاقى فراگيران مطرح شده است. در اين راستا، يافتههاى يزوهش امينى مشهرى و غفارى (r (I I) بيانگر آن است كه نظام آموزش و يرورش ايران بهمنظور تحول ارزشى نيازمند آن است كه به همان ميزان كه به تربيت دينى توجه دارد، به تربيت اخلاقى نيز بهعنوان رويكردى مهمم در قلمرو تربيت ارزشى توجه داشته باشد؛ جرا كه اخلاقيات در دين اســلام، اهميت بسيار والايى دارد. به همين دليل به زعم محققان از جمله حاجى بابائيان اميرى (هوس ( ) تربيت اخلاقى بايد در رأس برنامههاى تربيتى باشد؛

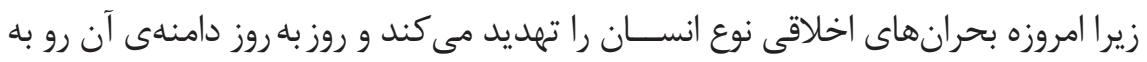
گَسترش است. بدين لحاظ يكى از معضلاتى كه توجه روانشناسان و كارشناسان علومتربيتى را بيش از ييش به خود معطوف داشته، شيوع ناهنجارىهاى اخلاقى در ميان اقشار مختلف جامعه، باهويزه نوجوانان است؛ زيرا از منظر علم روانشناسى دوره نوجوانى، از مراحل بسيار مهم تحول شخصيت بلشمار مىرود كه اوج بروز عواطف، قدرت غرايز و حاكميت احساسات است و به مراتب دشوارتر و حساستر از دوره كودكى است؛ جرا كه اين دوران، بحرانىترين مرحله زندگى اســت كه روان و جسم فرد دستخوش تغيير و دگر گونى مى شود و جنانجه فرد در معرض انحراف قرار گيرد به ســرعت، رفتارهاى بههنجار او به رفتارهاى نابههنجار تبديل مى گردد (نساجى، هوس ا: ه ه). در مجموع به اذعان اكثر يروهشخران از جمله كيان (צ૧ (1) مىتوان كَفت كه نقش برنامههاى درسى و طراحان آن، در تحقق تربيت اخلاقى و دينى بسيار حساس است و فقدان برنامهريزى ماهر و با صلاحيت، آسيب جدّى در اين زمينه قلمداد مىشود. به عبارت ديخر، مىتوان بيان داشت كه تربيت اخلاقى در فرهنگ خانواده شكل گرفته و ادامه مىيابد و يس از آن، در فرهنَ آموزشى و برنامههاى درسى 
مؤسسهاى تربيتى كامل مىشود. بنابراين با مرور تحقيقات يِيشين مىتوان نتيجه گيرى

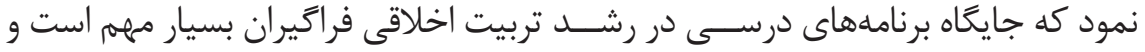

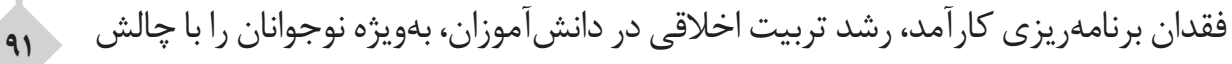

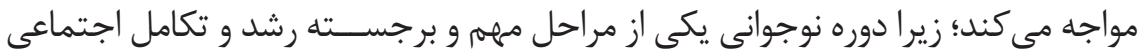
و روانى فرد بهشمار مىرود. در اين دوره احتياج به تعادل هيجانى و عاطفى بهويزه تعادل

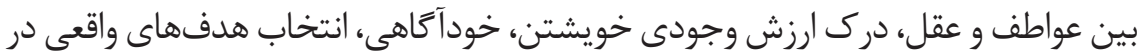
زندكى، اســتقلال عاطفى از خانواده، حفظ تعادل روانى و عاطفى خويش در مقابل عوامل فشارزاى محيطى، برقرارى روابط سالم با ديخران، كسب مهارتهاى اجتماعى لازم، شناخت

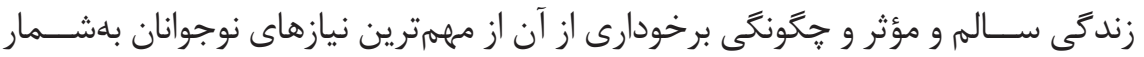

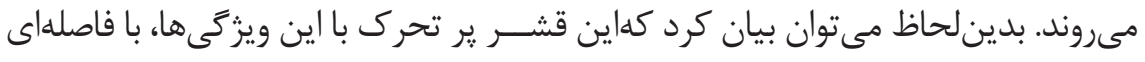

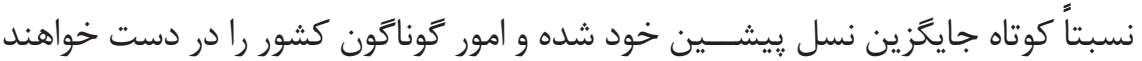

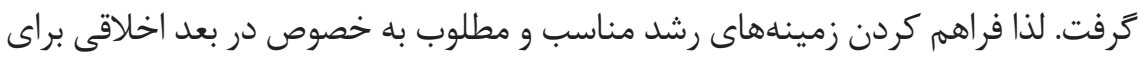

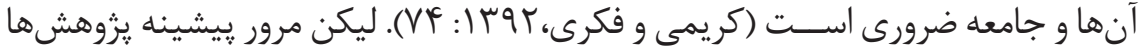

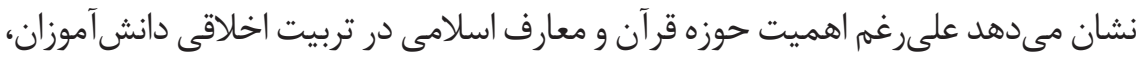

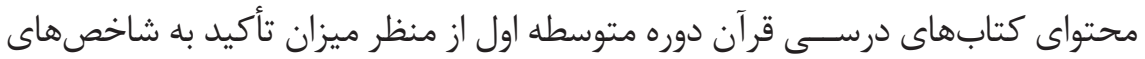
رويكرد اسلامى در تربيت اخلاقى تا كنون مورد بررسى و تحليل يزوهشكَران قرار نكرفته

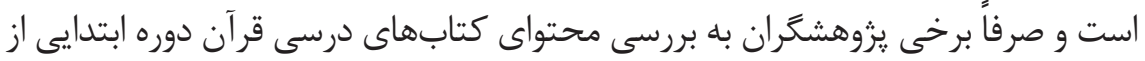

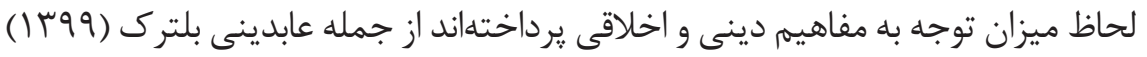

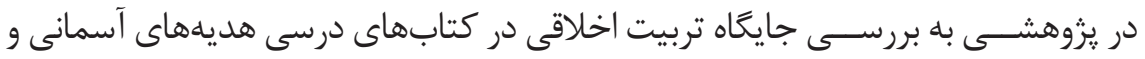

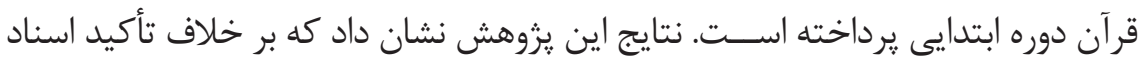

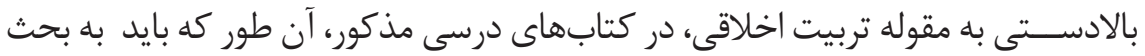
تربيت اخلاقى يرداخته نشده است.

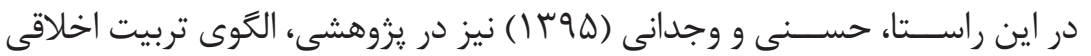

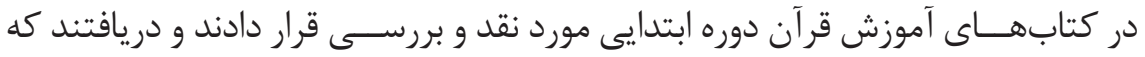

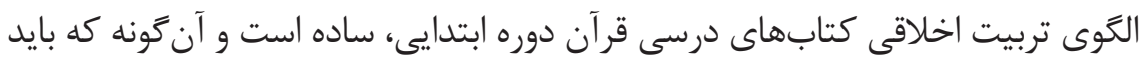

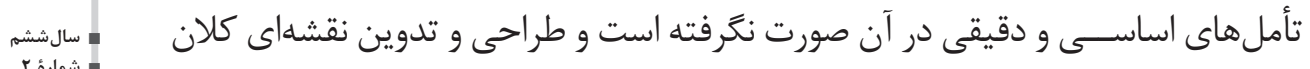


افكارى (سوس () نيز در رساله دكترى خود، ضمن شناسايى ف مؤلفه تربيت اخلاقى در رويكرد اسلامى، محتواى كتابهاى درسى دوره ابتدايى از جمله كتابهاى درسى قرآن را از منظر ميزان توجه به مؤلفههاى مذكور مورد بررسى قرار داد. نتايجاين يزوهش نشان داده است كه علىرغم اهميت نقش نهاد آموزش و يرورش در جريان تربيت متربيان و نيز محور بودن اساسـى كتابهاى درسى در جريان تعليمى و تربيت، در كتابهاى درسى قرآن دوره ابتدايى به مســـله مهرمى جون تربيت اخلاقى بهطور علمى :برداخته نشده و اكثر مطالب كتابهاى درسى مذكور به شكل مضمونهايى حاوى يند و اندرز ارائه گَرديده و براى ارتباط مؤلفههاى تربيت اخلاقى با زندگى روزمره دانشآموزان فعاليتى پيش بينى نشده است. درامامى ( • و ا ) در يايان نامه كارشناسى ارشد خود به تحليل محتواى كتابهاى درسى

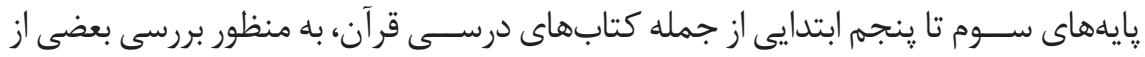
مؤلفههاى تربيت اخلاقى (مانند صداقت، احترام به خود و ديخران، امانتدارى، وفاى به عهد، نيكى به والدين و مهربانى) و نيز شيوه ارائه آنها يرداخت و دريافت كه بهرغم نقش كليدى نهاد آموزش و يرورش در فرايند تربيت فراخيران و نيز نقش اساسى كتابهاى درسى در فرايند تعليم و تربيت، در كتابهاى درسى قرآن دوره ابتدايى به مسئله مهمى جون تربيت اخلاقى بلهور جدى يرداخته نشده و بيشتر مطالب كتابهاى درسى نامبرده به شكل مضمونهاى انتزاعى ارائه شــده و از شيوههاى مناسب با ســن دانش آموزان، كمتر بهره برده شده است.

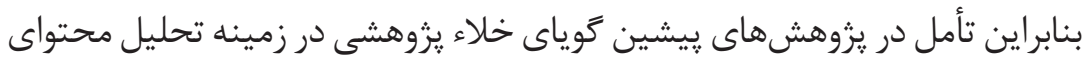
كتابهاى درسى قرآن دوره متوسطه اول بر اساس ميزان تأكيد به شاخصهاى رويكرد اسلامى در تربيت اخلاقى اسـت. لذا با عنايت به لزوم یر كردن خلاء مطالعاتى موجود، نقد و بررسـى محتواى كتابهاى درسى قرآن دوره متوسطه اول بر اساس ميزان توجه به شاخصهاى رويكرد اســلامى در تربيت اخلاقى ضرورى به نظر مىرسد. بدين لحاظ يروهش حاضر با هدف شناسايى شاخصهاى رويكرد اسلامى در تربيت اخلاقى و تحليل محتواى كتابهاى درسى قرآن دوره متوسطه اول بر مبناى ميزان توجه به آن شاخصها انجام شد. لذا يرسش هاى يثوهش فعلى عبارتند از: ا. شاخصهاى اساسى رويكرد اسلامى در تربيت اخلاقى كدامند؟ r. ميزان توجه به شاخصهاى رويكرد اسلامى در تربيت اخلاقى در كتابهاى درسى

$$
\text { قرآن دوره متوسطه اول گُخونه است؟ }
$$




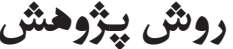

يزوهش فعلى با تر كيبى از روش هاى مطالعات كتابخانهاى، دلفى فازى، تحليل محتواى

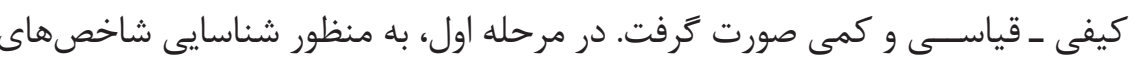
رويكرد اسلامى در تربيت اخلاقى، از روش مطالعات كتابخانهاى استفاده شد. در بخش

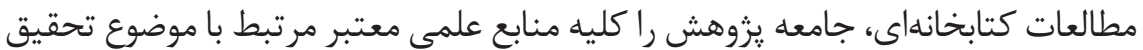

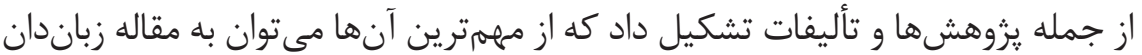

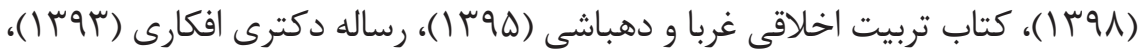

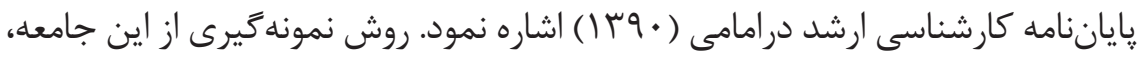

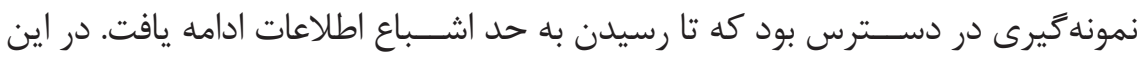
بخش، براى جمعآورى دادهها از فيش و براى تجزيه و تحليل دادههاى كيفى حاصل از داز

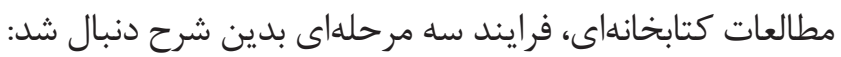

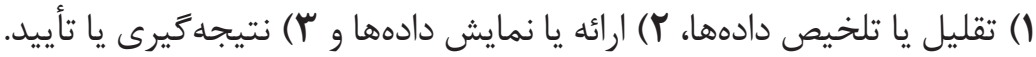

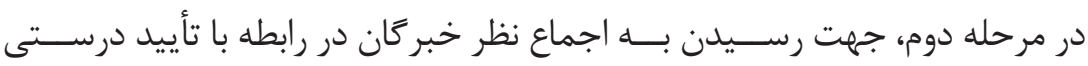
شــاخصهاى استخراج شــده، از روش دلفى ـ فازى بهرهبردارى شد. روش دلفى فازى

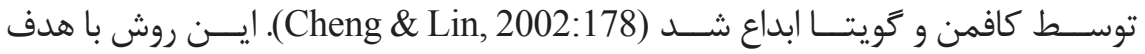

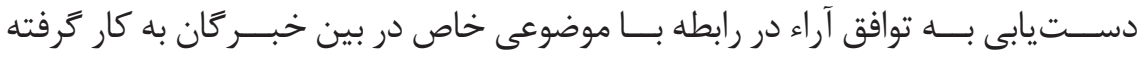

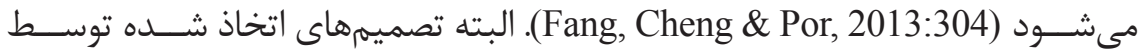

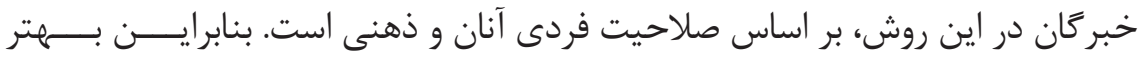

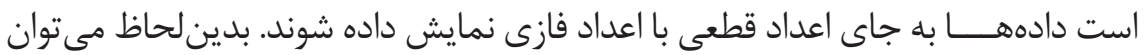

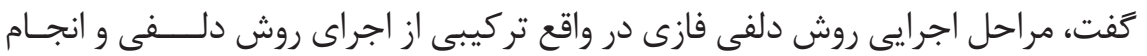

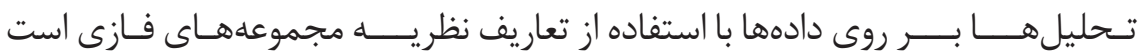

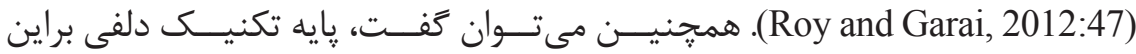

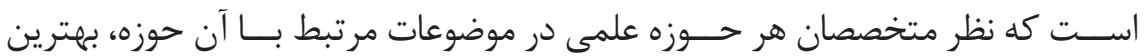

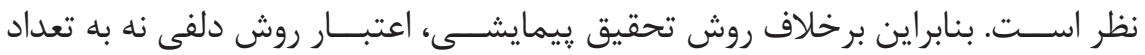

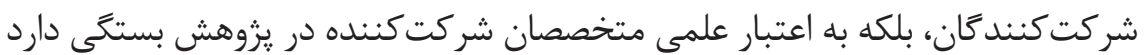

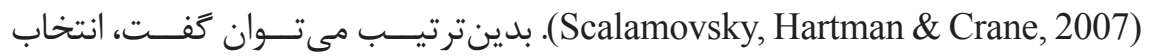

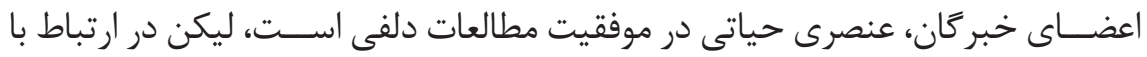


تعــداد خبر Fان مورد نياز براى دلفى ســـتـى و دلفى ـ فازى اجمـــاع نظر وجود ندارد. بهullen, 2003:41) تغيير است؛ جرا كه از يك منظر، تعداد اعضاى گروه خبر ₹ان بايد به اندازه كافى باشد تا

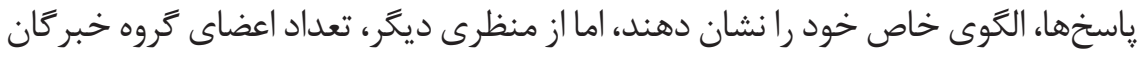

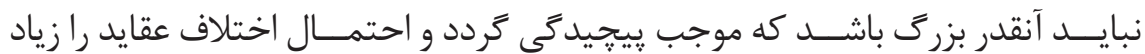
نمايد (Okoli and Pawlowski, 2004). بدين لحاظ در بخش دلفى فازى، جامعه آمارى را اســـاتيد شاغل در دانشخاههاى اســـان همدان در رشتههاى علومتربيتى، روانشناسى و الهيات در ســال وqجا تشــكيل داد كه · ع نفر از آنها بهصــورت هدفمند بهعنوان نمونه آمارى انتخاب شـــند. در اين بخش، براى جمعآورى دادهها از يرسشنامه محقق ســاخته حاوى T I شاخص رويكرد اسلامى در تربيت اخلاقى در قالب طيف ليكرت ينج درجهاى از خيلى زياد تا خيلى كم بهرهزيرى شــد كه بر اســاس شاخصهاى استخراج شــده در مرحله قبل طراحى شــد. روايى صورى و محتوايى :رسشنامه توسط جمعى از متخصصان بررســى و تأييد شد. جهت سنجش يايايى زرســشنامه از ضريب آلفاى كرونباخ بهرهبردارى شــد كه ضريب 11/ • به دست آمد و در نهايت تأييد شد. از معيار اعتبار اعضا در شيوه اعتباريابى نيومن نيز براى بررسى اعتبار دادهاى مربوط به تكنيك دلفى فازى اســـفاده شد. اعتبار اعضا در معيار اعتباريابى نيومن زمانى اتفاق مىافتد كه يــــ محقق، نتايج حاصله را به اعضا برمى گر داند تا در مـــورد كفايت آن داورى نمايند

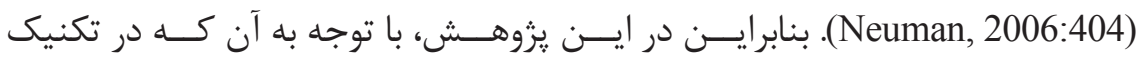
دلفى - فازى، نتايج مربوط به هر مرحله به خبر گان بركشت داده شد و نظر آنها مجدداً دريافت گرديد، اعتبار اعضا برقرار است. همجنين جهت تجزيه و تحليل دادههاى كمى مإى حاصل از دلفى فازى، از شاخصهاى آمار توصيفى نظير فراوانى استفاده گرديد. در مرحله سوم، به منظور تحليل محتواى كتابهاى درسى قرآن دوره متوسطه اول

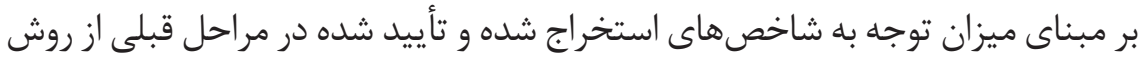
تحليل محتواى كيفى ـ قياسى و كمى بهرهگيرى شد. تحليل محتواى كيفى ـ قياسى با استفاده از نظريdها و رويههاى موجود، تجربdها يا دانش متخصصان و تحقيقات ييشين آغاز مى شود. مفهومها و متغيرها، مقولهها و كدها و روابط ميان آنها و سازههاى تحليل،

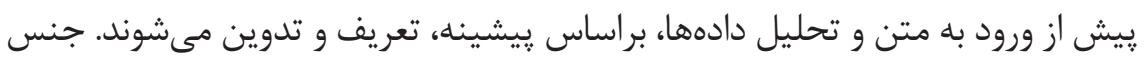


استنتاج قياس است كه اطلاعات و دانش موجود را براى فهم اشياء يا شكل دادن به آراء

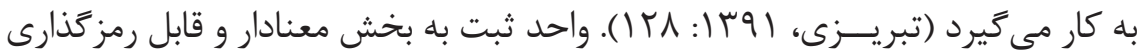
محتوا اطلاق مىشـــود. از اين رو، واحد ثبت در اين تحليل رابـ را مضامين تشكيل داد؛ زيرا

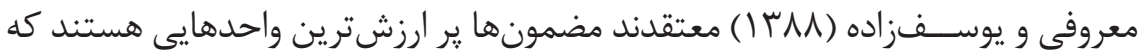

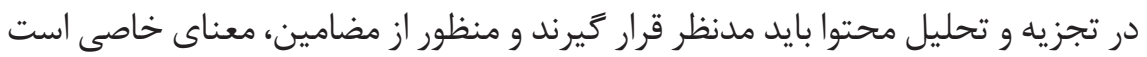

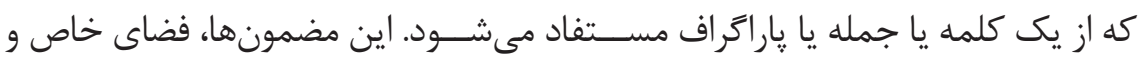

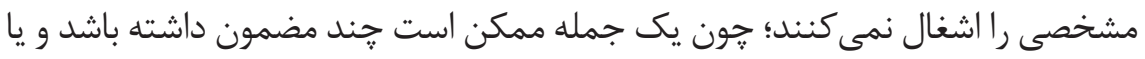

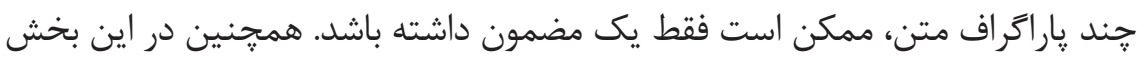

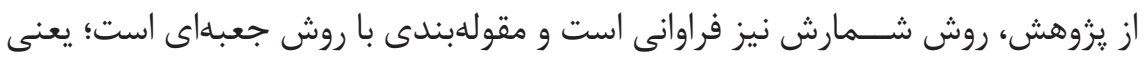

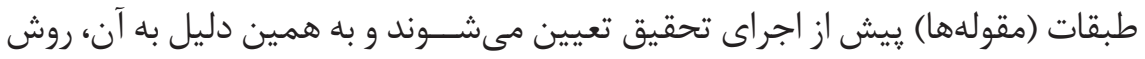

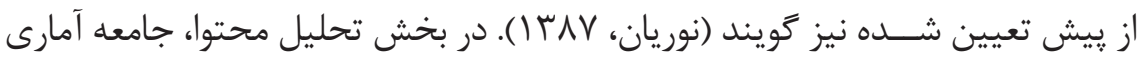

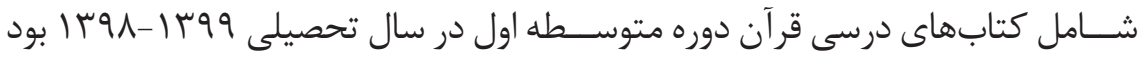

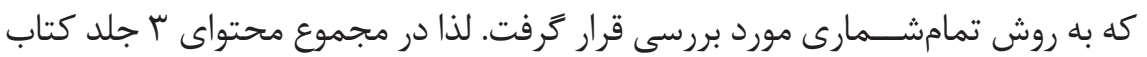

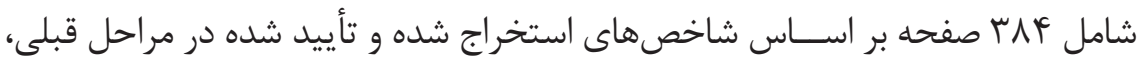

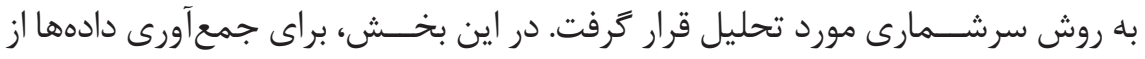

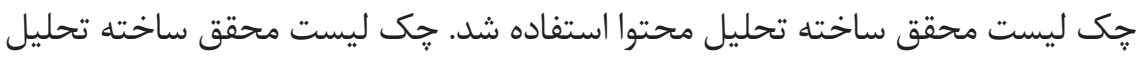
محتوا بر اساس شاخصهاى اســتخراج شده از تحليل منابع علمى در دسترس و و تأييد

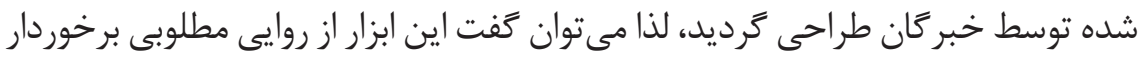

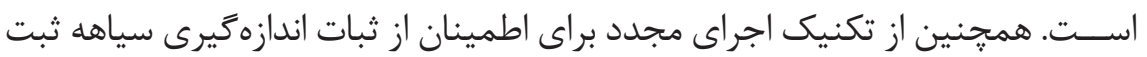

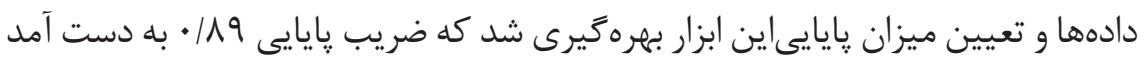

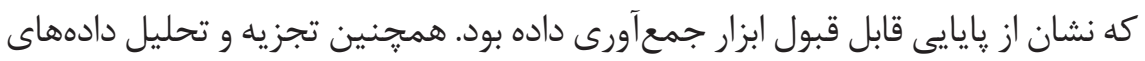

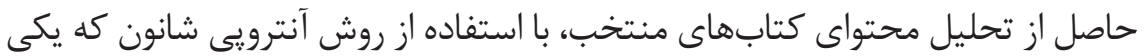

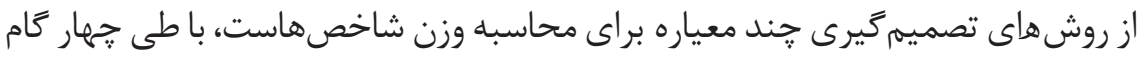

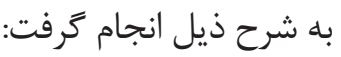
() تشــكيل ماتريس تصميم يزوهش كه سطرها مشتمل بر كتابهاى درسى قرى قرآن

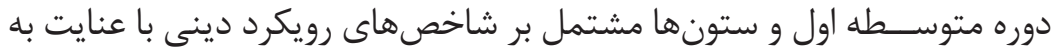


ץ) تشكيل ماتريس تصميم نرمال شده با استفاده از روش نرمال سازى ساده، بهمنظور تبديل دادهها به دادههاى بهنجار شده؛ r) محاسبه مقادير مربوط به آنترويى هر شاخص؛ F (F) محاسبه مقادير مربوط به وزن هر شاخص.

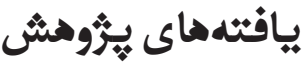

ياسخ به يرســــ اول هزوهش: شاخص هاى اساســى رويكرد اسلامى در تربيت

$$
\text { اخلاقى كدامند؟ }
$$

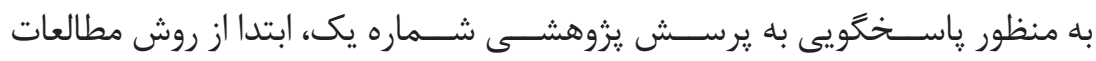
كتابخانهاى جهرت استخراج شاخصهاى رويكرد اسلامى در تربيت اخلاقى، مطلوبِ دوره اول متوسطه از تحليل منابع علمى در دسترس تا رسيدن به حد اشباع اطلاعات استفاده شد، سيس از تكنيك دلفى فازى با طى مراحل ذيل جهت رسيدن به اجماع نظر خبر گان

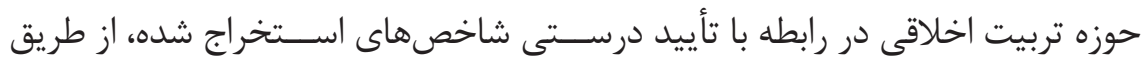
تكميل يرسشنامه محققساخته بهره گيرى شد:

متعريف متغيرهاى كلامى: در جدول شـماره ( (1) دامنه متغيرهاى كيفى تعيين شده است تا خبر گان با ذهنيت يكسان به سؤال ها ياسخ دهند.

$$
\text { جدول شماره ا. اعداد فازى مثلثى متغيرهاى كلامى }
$$

\begin{tabular}{|c|c|c|}
\hline عدد فازى قطعى شده & عدد فازى مثلثى & متغير هاى كلامى \\
\hline . $/ 9$ TVD & $(1, \cdot / r \Delta, \cdot)$ & خيلى زياد \\
\hline$\cdot / V \Delta$ & $(\cdot / V \Delta, \cdot / / \Delta, \cdot / / \Delta)$ & زياد \\
\hline$\cdot 10$ & $(\cdot / \Delta, \cdot / r \Delta, \cdot / r \Delta)$ & متوسط \\
\hline$\cdot / T \Delta$ & $\left(\cdot / r \omega_{g}, / / \Delta, g / / \mid \Delta\right)$ & كم \\
\hline $.1 .9 T \Delta$ & $(\cdot g \cdot g \cdot / / \Delta)$ & خيلى كم \\
\hline
\end{tabular}




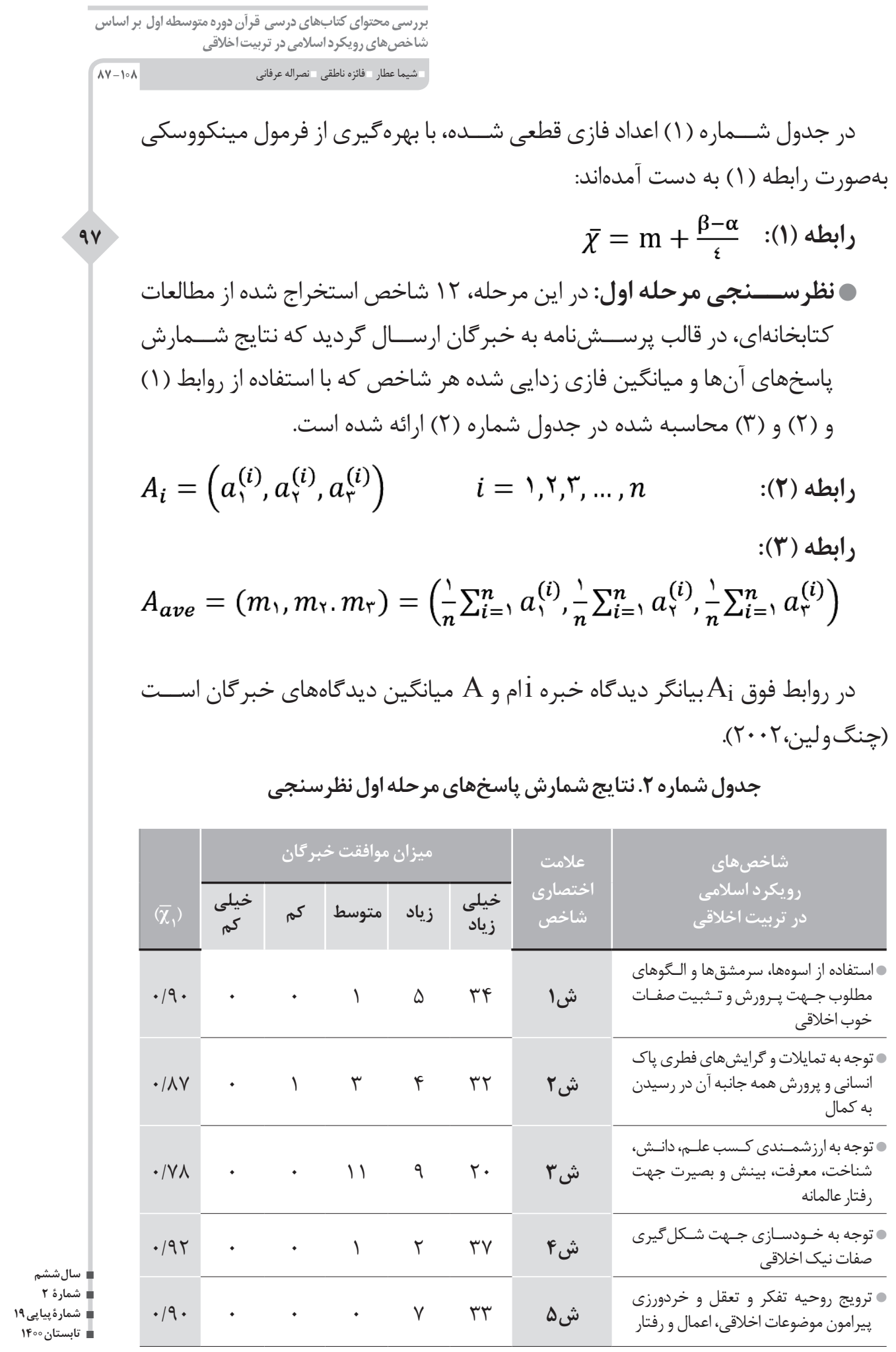




\begin{tabular}{|c|c|c|c|c|c|c|c|}
\hline & & & & & & & \multirow[b]{2}{*}{ فصلناهه (علمى-يثوهشى) } \\
\hline & & & & & & & \\
\hline & & & & & & & مسائل كاربردى تعليمو تربيت اسلامى \\
\hline \multirow[b]{2}{*}{$\left(\bar{\chi}_{1}\right)$} & \multicolumn{5}{|c|}{ ميزان موافقت خبر كان } & \multirow{2}{*}{ شاخلامت } & \multirow{2}{*}{ در ريكرد اسلامى ثاى } \\
\hline & 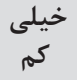 & كم & متوسط & 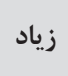 & 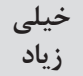 & & \\
\hline$\cdot / \mathrm{A} \wedge$ & • & • & $1 \cdot$ & $1 \cdot$ & $r \cdot$ & ش & 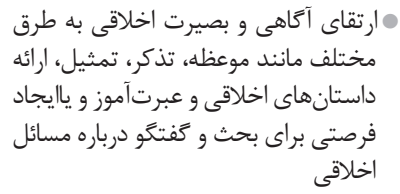 \\
\hline$\cdot \mid \Lambda F$ & • & • & $\Delta$ & 9 & rq & ش V V & ص تأكيد به خودشكوفايى جهت شكل خيرى \\
\hline$\cdot|\Lambda|$ & - & • & $1 \cdot$ & f & rq & شی & فضايل اخلاقى به معروف جهت دعوت به \\
\hline$\cdot / \Lambda \Delta$ & - & • & $\Delta$ & V & rᄉ & ش9 & ه توجله به نهى از منكر جهت دورى از رذايل \\
\hline$\cdot / 9$. & - & • & $\cdot$ & V & 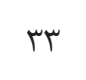 & ش 1. & ص تمركز بطرب خودشناسى جهت شكل خيرى \\
\hline$\cdot / \Lambda \mathrm{V}$ & • & • & r & V & r. & ش11 & 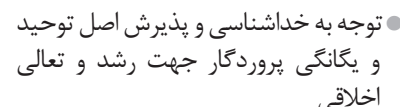 \\
\hline$\cdot / V V$ & • & • & If & f & tr & ش شا & 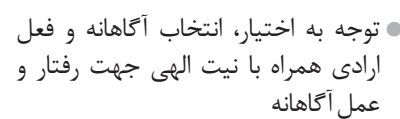 \\
\hline
\end{tabular}

يافتههاى جدول شماره (T) نشان مى دهد كه خبر كان درباره بيشتر شاخصها توافق نظر زيادى دارند.

○ نظرسنجى مرحله دوم: در اين مرحله، نظرات خبركان در خصوص معرفى ساير

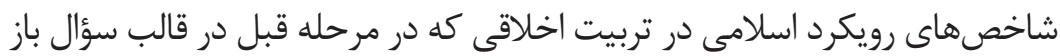

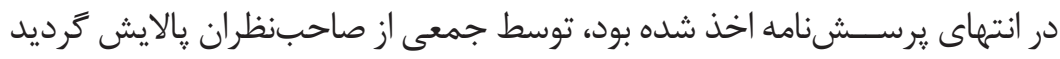

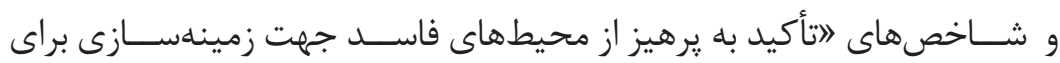

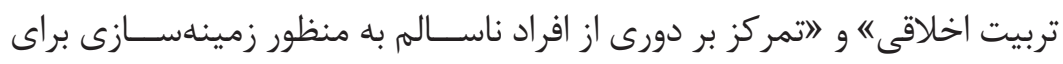

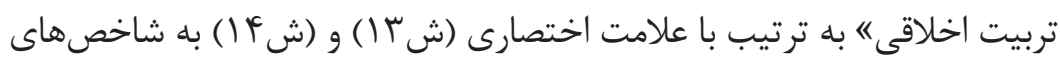

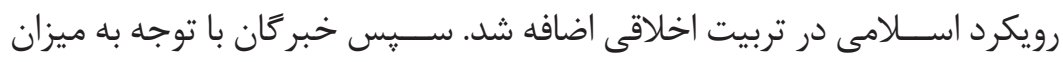

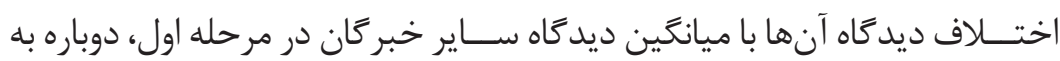




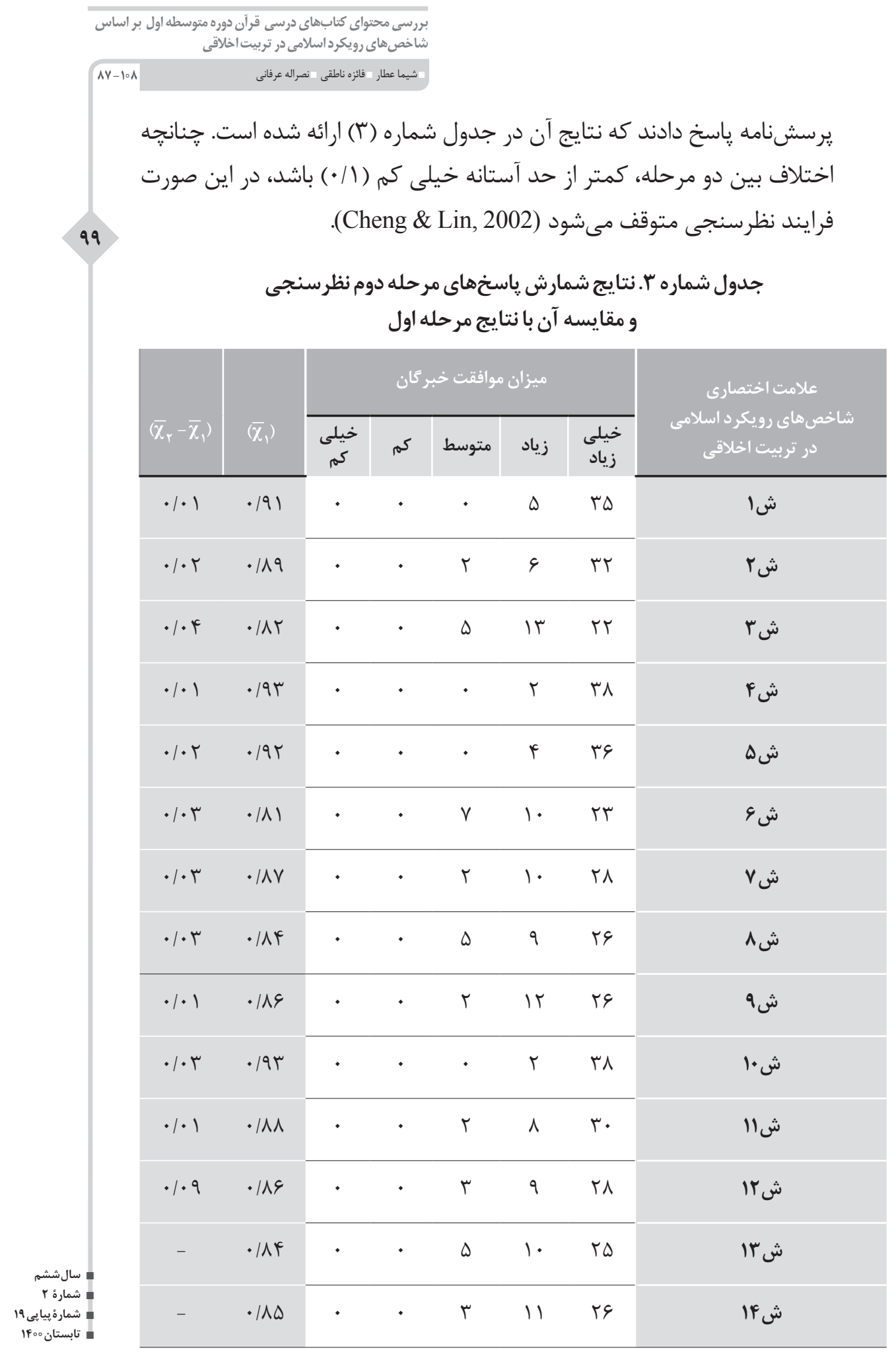




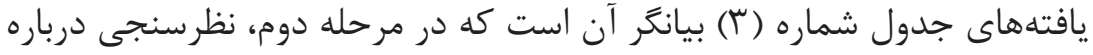
זا شــاخصى كه ميزان اختلاف نظر راجع به آنها كمتر از ( / • ) مىباشــد، متوقف

نظرسنجى مرحله سوم: در اين مرحله، خبر كان با توجه به ميزان اختلاف ديدگاه

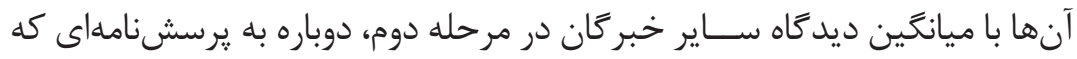

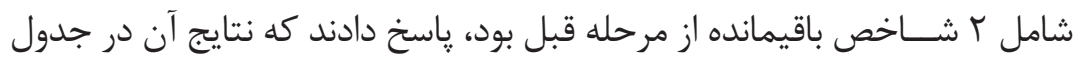
شماره (Y) (Y) آمده است.

\section{جدول شماره F. نتايج شمارش ياسخهاى مرحله سوم نظرسنجى و مقايسه آن بانتايج مرحله دوم}

\begin{tabular}{|c|c|c|c|c|c|c|c|}
\hline \multirow[b]{2}{*}{ () } & \multirow[b]{2}{*}{ () } & \multicolumn{5}{|c|}{ ميزان موافقت خبركان } & \multirow{2}{*}{ علامت اختصارى شاخصرهاى اسلامى در تربيت } \\
\hline & & خيلى & كم & متوسط & زياد & خيادى & \\
\hline r.|. & - /AV & • & • & 1 & 15 & rV & ش سו \\
\hline$\cdot 1 \cdot f$ & .119 & • & • & • & 11 & rq & ش \\
\hline
\end{tabular}

يافتههاى جدول شماره (Y) حاكى از آن است كه در مرحله سوم، نظرسنجى درباره r شــاخص فوق كه ميزان اختلاف نظر راجع به آنها كمتر از (1/•) مىباشد، متوقف

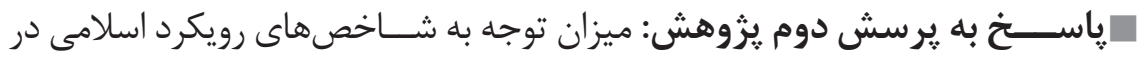
تربيت اخلاقى در كتابهاى درسى قرآن دوره متوسطه اول جُخونه است؟

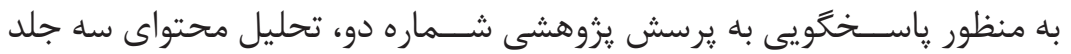
كتاب درســى قرآن دوره متوسطه اول بر اساس ميزان توجه به شاخصهاى رويكرد اســلامى در تربيت اخلاقى مد نظر بوده كه نتايج حاصل از آن در جدول شماره (ه) 


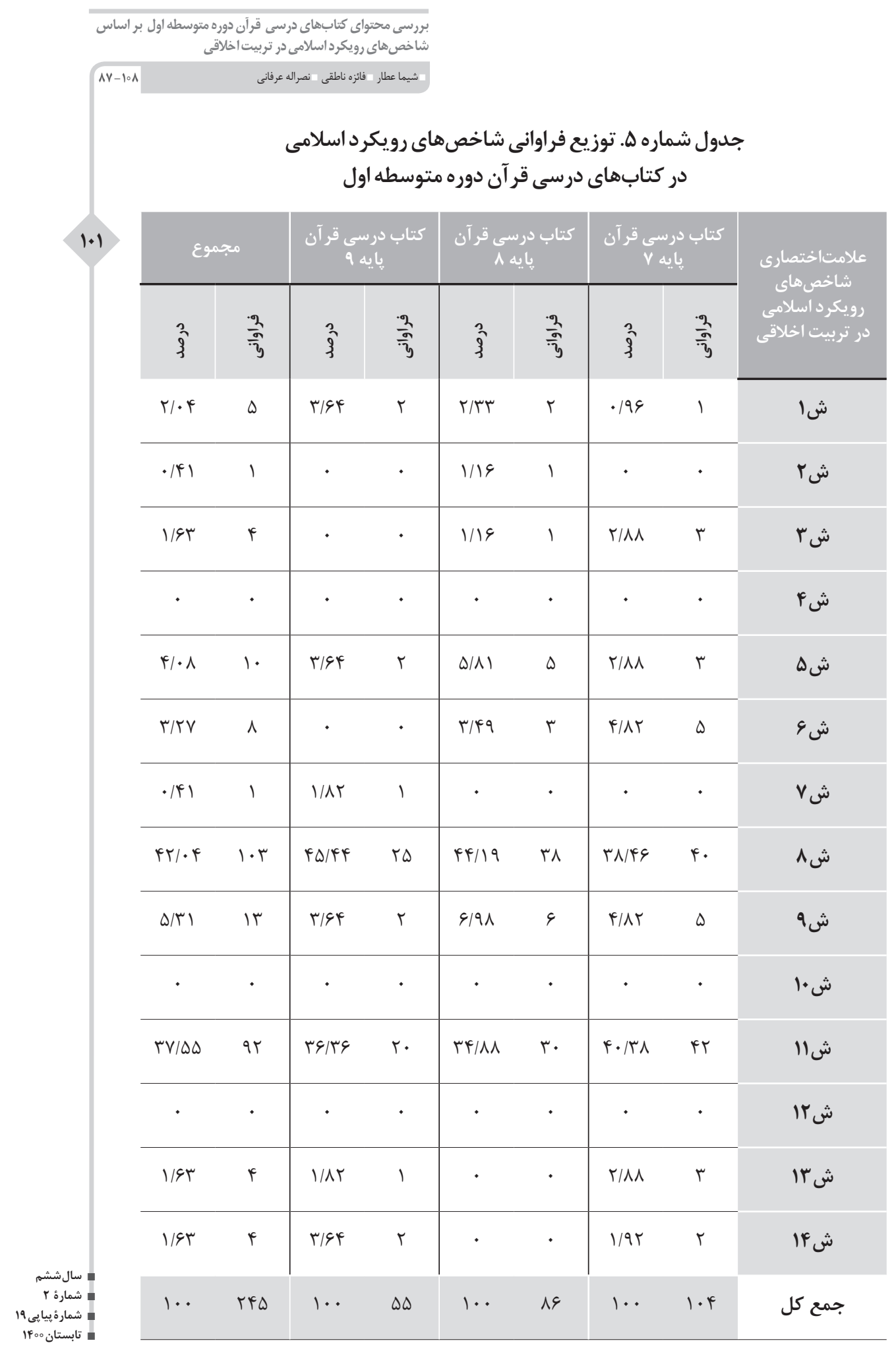


يافتههاى جدول شــماره (ه) نشـــان مىدهد كه از ميان كل مضامين مطرح شـــه

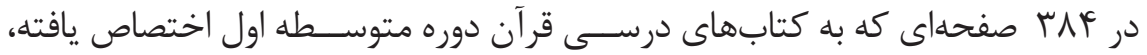
بيشـــرين فراوانى مربوط به شاخص هشــتم با س • ا مضمون و كمترين فراوانى مربوط به شــاخصهاى جههارم، دهم و دوازدهم با • مضمون است. در ادامه نيز جهت تجزيه و تحليل دادههاى حاصل از تحليل محتوا از روش آنترويى شانون با استفاده از روابط ذيل بهرهبردارى گرديده كه نتايج آن در جدول شماره (9) آمده است.

جدول شماره 9. مقادير بار اطلاعاتى و ضريب اهميت شاخصهاى رويكرد اسلامى ديى در كتابهاى درسى قرآن دوره متوسطه اول

\begin{tabular}{|c|c|c|c|c|c|c|c|c|c|c|c|c|c|c|}
\hline ش & ش & ش & $\begin{array}{l}\text { ش } \\
\text { ش }\end{array}$ & $\begin{array}{l}\text { ش } \\
\text { 1. }\end{array}$ & $\begin{array}{l}\text { ش } \\
\text { ش }\end{array}$ & $\begin{array}{l}\text { ش } \\
\Lambda\end{array}$ & $\begin{array}{l}\text { ش } \\
\text { V }\end{array}$ & $\begin{array}{l}\text { ش } \\
\text { ش }\end{array}$ & $\begin{array}{l}\text { ش } \\
\text { ش }\end{array}$ & ش & ش & ش & ش & شاخصها \\
\hline • & $\cdot(01)$ & • & .199 & . &.$/ 941$ & - $/ 9 \Lambda T$ & . & $\cdot 19 \cdot T$ & •/9TV & • & $\cdot 1011$ & • &.$/ 99$ & $\left(E_{j}\right)^{*}$ \\
\hline .1 .9 & & & • /ITV & . & •/ITI & $/ \| F$. & . & $\cdot 1 \cdot 19$ &.$/ M F$ & . & $\cdot / \cdot V r$ & . & . /IrV & $\left(W_{j}\right)$ \\
\hline
\end{tabular}

* $\mathrm{K}=\cdot / 91 \cdot r$ rqrtr

يافتههاى جدول شــماره (9) حاكى از آن اســت كه در كتابهاى درسى قرآن دوره اول متوســـه بيشـــترين بار اطلاعاتى و ضريب اهميت مربوط به شاخص لاتوجه به امر به معــروف جهت دعوت به فضايل اخلاقى" و كمترين بــار اطلاعاتى و ضريب اهميت مربوط به شــاخصهاى لاتوجه به تمايلات و گر ايشهاى فطرى گاك انســانى و يرورش همه جانبه آن در رسيدن به كمال"، لاتوجه به خودسازى جهت شكل خيرى صفات نيك اخلاقى"، لاتأكيد به خودشــكوفايى جهت شكل گيرى صفات مناسب اخلاقى"، لاتمر كز بر خودشناسى جهت شــكل گيرى صفات مطلوب اخلاقى" و "اتوجه به اختيار، انتخاب آكاهانه و فعل ارادى همراه بانيت الهى جهت رفتار و عمل آخاهانه/ مىباشد.

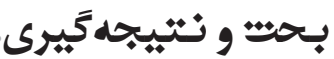

در اين بخش از يزوهش، ابتدا هر يك از يافتههاى يثرهش به تفكيك يرســشهاى

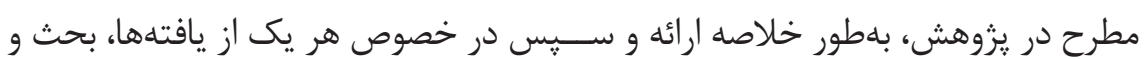
نتيجه گيرى مهى مطرد: 
بررسى محتواى كتابهاى درسى قرآن دوره متوسطه اول بر اساس

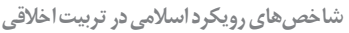

ن نتايج حاصل از برســـ اول يزوهش: شاخصهاى اساسى رويكرد /سلامى در

\section{تربيت اخلاقى كدامند؟}

يافتههــاى حاصل از مطالعــات كتابخانهاى و دلفى فازى نشــان داد كه

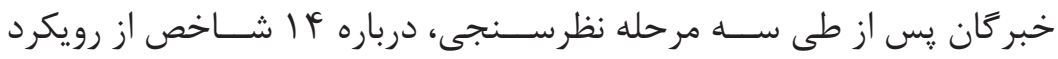

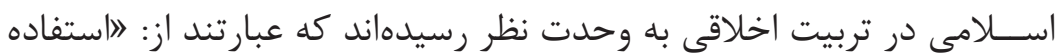

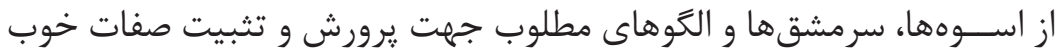

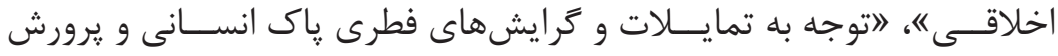

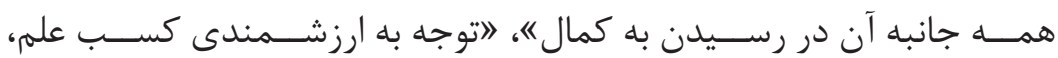
دانش، شــناخت، معرفت، بينش و بصيرت جهت رفتــار عالمانها،، اتوجه به

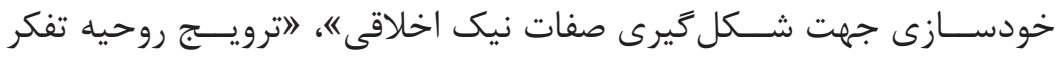

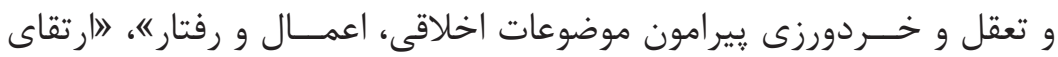

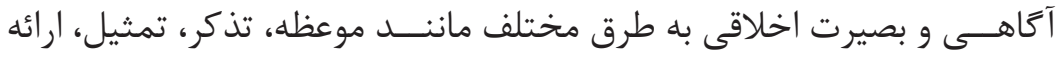
داستانهاى اخلاقى و عبرتآموز و ياايجاد فرصتى براى بحث و و كفتختو درباره

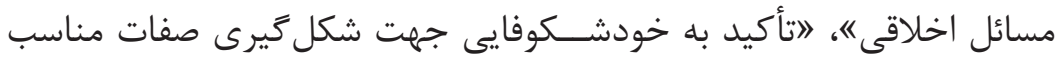
اخلاقى"، "توجه به امر به معروف جهــت دعوت به فضايل اخلاقى"، لاتوجه

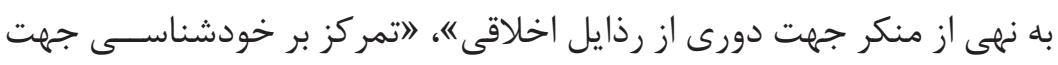

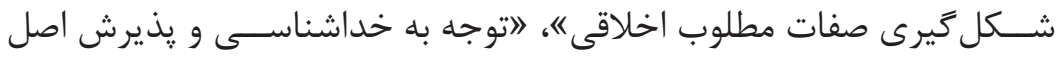

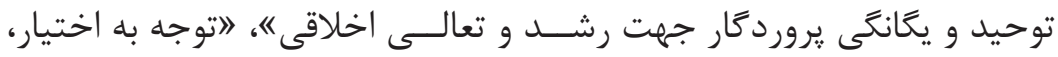

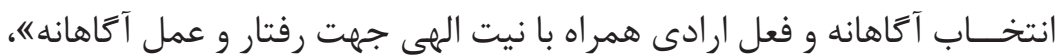

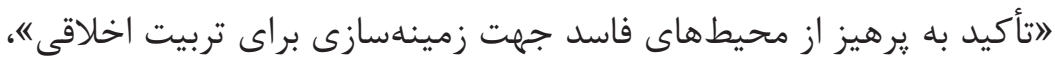

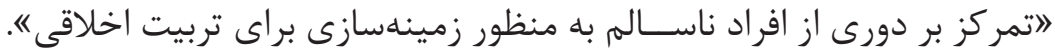

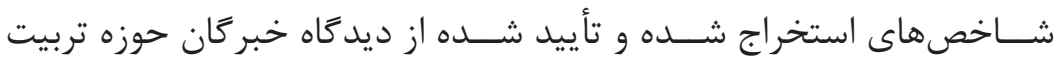

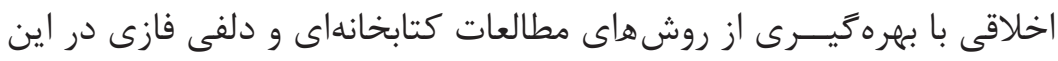

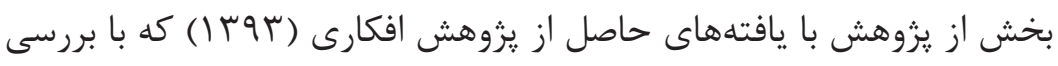

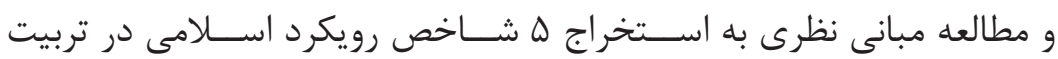

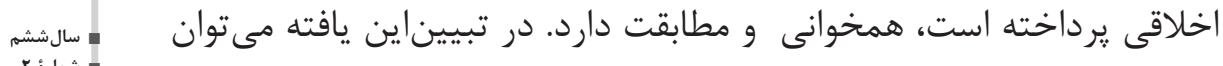


و شــناخت و تمايل هر دو مقدمه رفتار عالمانه هستند، اگر گه كه گرايشها به تنهايى نيز مىتوانند منجر به رفتار شوند، اما رفتار عالمانه فقط با شناخت و بصيرت ممكن است كهاين نتيجه با يافتههاىاين يزوهش و يزوهش افكارى

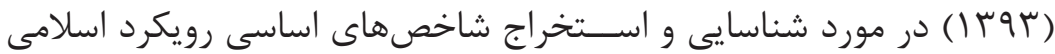
در تربيت اخلاقى همسو مىباشد.

نتايج حاصل از يرسش دوم يثوهش: ميزان توجه به شاخصهاى رويكرد /سلامى در تربيت اخلاقى در كتابهاى درسى قرآن دوره متوسطه اول جَّونه است؟ يافتههاى حاصل از تحليل محتواى كيفى - قياسى و كمى كتابهاى درسى قرآن دوره متوسطه اول بر مبناى ميزان توجه به شاخصهاى رويكرد اسلامى در تربيت اخلاقى حاكى از آن اســت كه توزيع شاخصهاى رويكرد مذكور در محتواى كتابهاى درسـىى نامبرده بهصورت نرمال و متوازن نيست. بهطورى كه يافتههاى آنترويى شــانون نيز نشان داد كه بيشترين بار اطلاعاتى و ضريب اهميــت مربوط به شــاخص لاتوجه به امر به معروف جهــت دعوت به فضايل اخلاقـى" و كمترين بار اطلاعاتــى و ضريب اهميت مربوط به شــاخصهاى

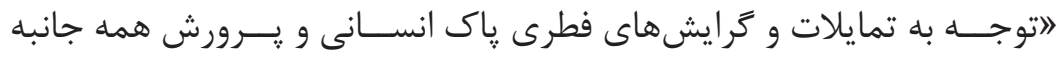
آن در رســيدن به كمال"، لاتوجه به خودسازى جهت شكل خيرى صفات نيك اخلاقى"، "اتأكيد به خودشكوفايى جهت شكل گيرى صفات مناسب اخلاقى"، "اتمركز بر خودشناسى جهت شكل گيرى صفات مطلوب اخلاقى" و لتوجه به

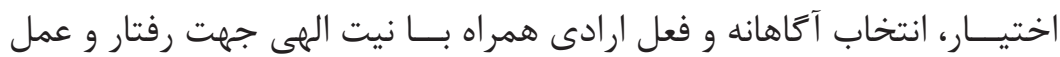

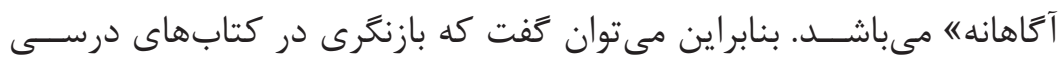
قرآن دوره متوسطه اول بر یايه شاخصهاى رويكرد اسلامى در تربيت اخلاقى ضرورى است. با توجه به اين كه يیشينه مشابهى با اين يافته در خصوص دوره اول متوسطه ييدا نشد، از اين رو امكان مقايسهاين يافته با يافتههاى تحقيقات يَيشين در دوره متوســـه اول فراهم نشد. ليكن با توجه به نتايجاين يزوهش

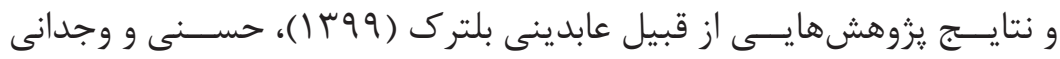

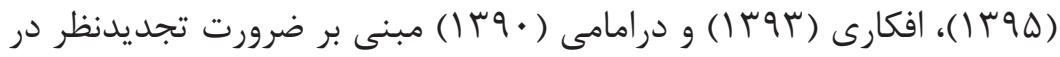
كتابهاى درسى قرآن دوره ابتدايى به دليل توزيع نامتعادل مؤلفههاى تربيت 
اخلاقى از ديدكاه اســلام در محتواى كتابهاى درسى نامبرده مىتوان كفت،

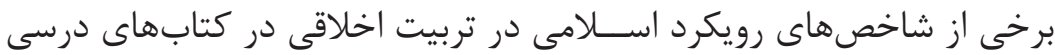
قرآن دورههاى تحصيلى ابتدايى و متوسطه اول حضور خشمًيرى نداشتهاند،

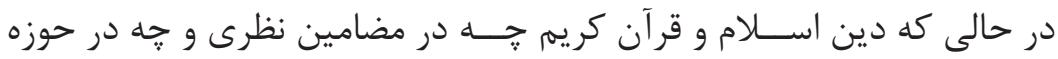

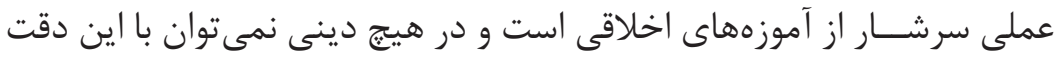

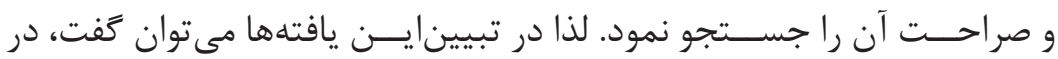
كتابهاى درسـى قرآن كليه دورههاى تحصيلى صرفاً بر روخوانى قرآن ترآن تأكيد

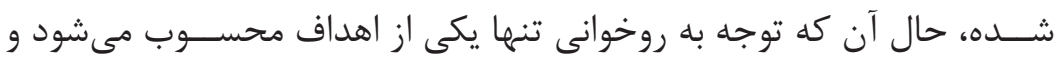

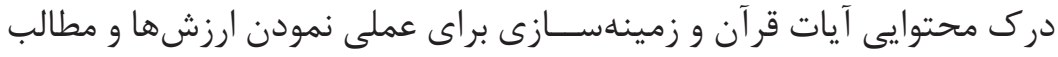

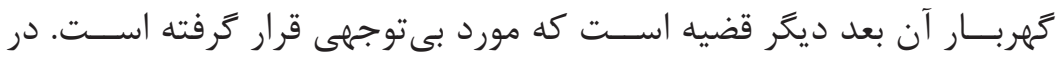

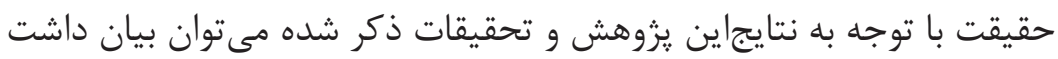

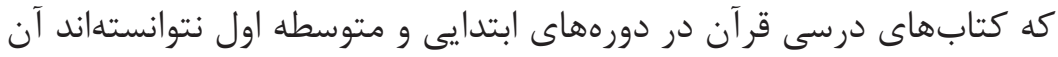

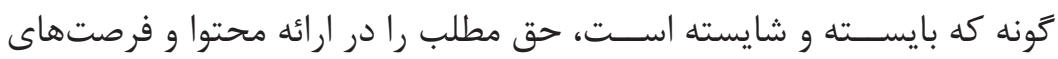

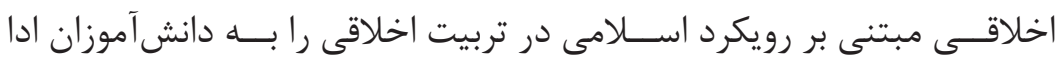

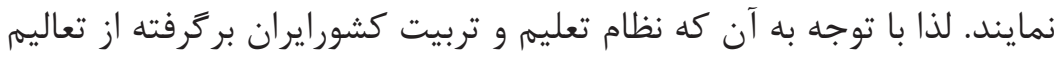

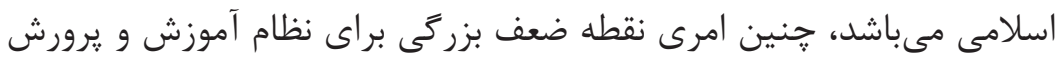

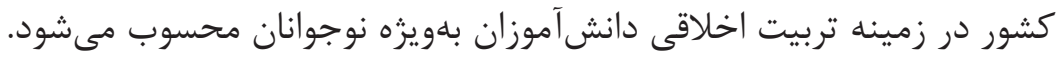

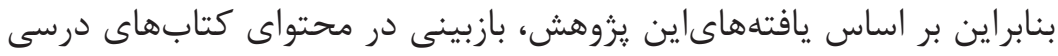

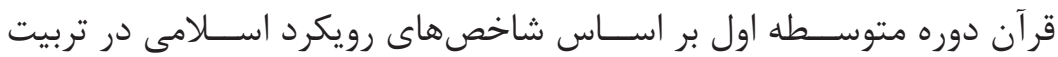

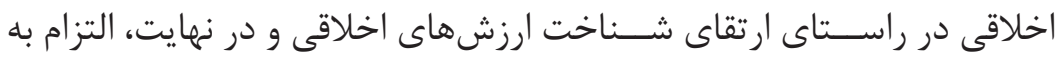

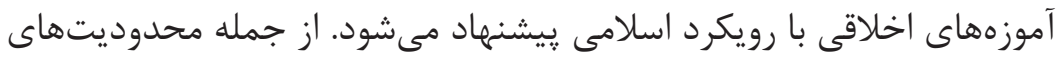

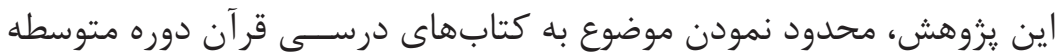

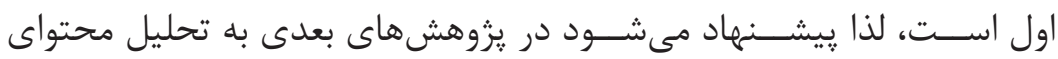

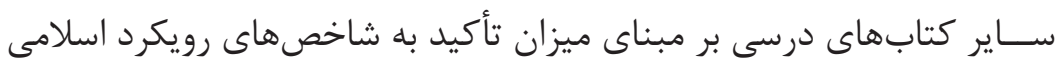

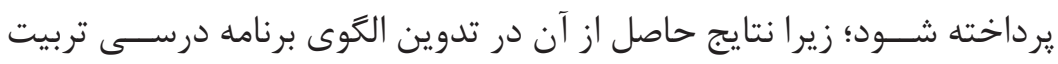

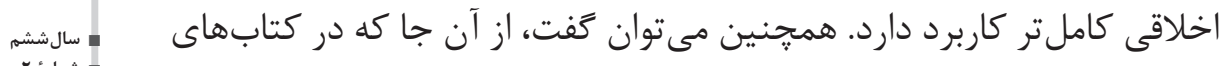

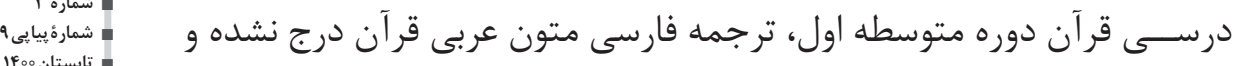


بر روان خوانى بيش از اهداف ديخر تأكيد شــده است، اين امر محدوديتهايى را در تحليــل محتواى كتابهاى درســى مذكور براى يزوهشـــــايجاد نمود. بنابراين متون فارسى كتابهاى درسـى قرآن دوره متوسطه اول ملاكى عمل قرار گرفت. براين اســاس، در تجديد نظر در محتواى كتابهاى درســى قرآن

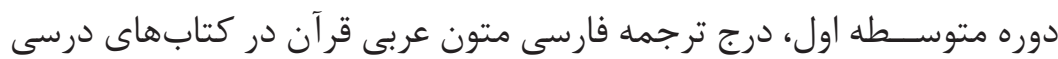
مورد اشــاره بهعنوان راهكارى براى طراحى و ارائه الخوى برنامه درسى تربيت

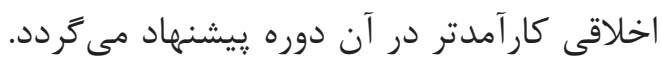

\section{تششكّر و قدردانى النى}

مقالهٔ حاضر، مستخرج از رسالهُ دكترى رشتهُ برنامهريزى درسى دانشخاه آزاد اسلامى واحد اراك با عنوان لانقد و بررسى جايگاه رويكردهاى تربيت اخلاقى در برنامة درسى دورة متوسطه اول و ارائه الكوى مطلوبه مىباشد. از اساتيد بزر ₹وار راهنما و مشاور و ساير اساتيد محترم گروه علوم تربيتى دانشخاه آزاد اسلامى واحد اراك، تقدير و تشكّر مى خردد. 


\section{منابع}

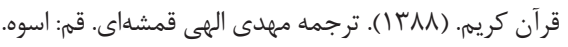

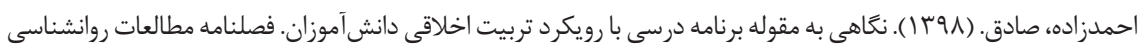

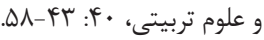

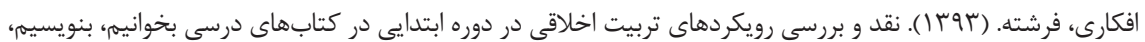

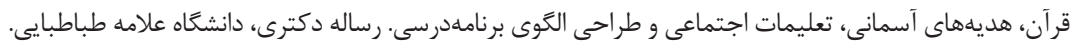

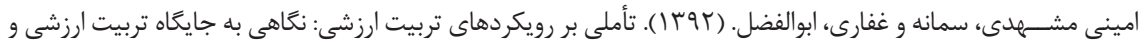

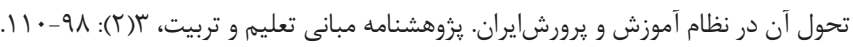

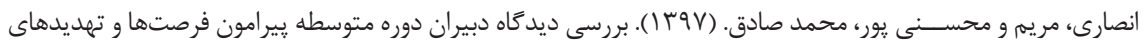

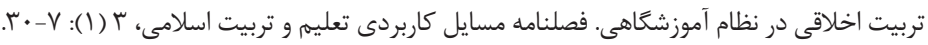

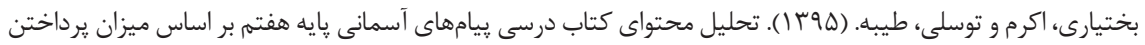

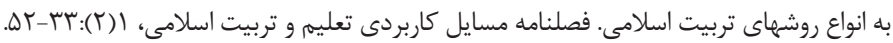

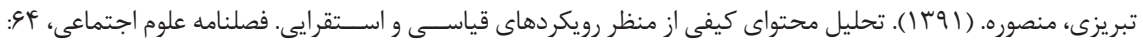
. I T $\Lambda-1 \cdot 0$

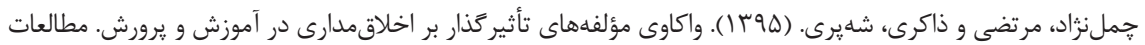

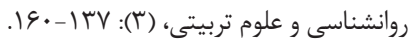

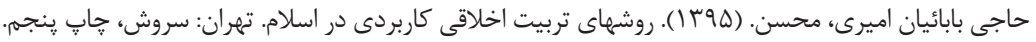

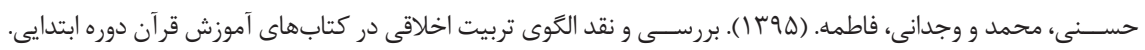

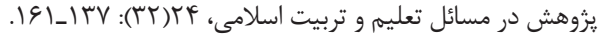

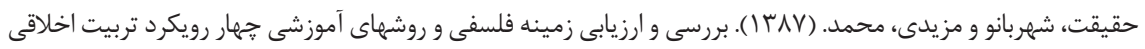

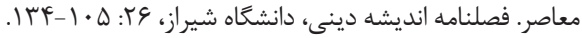

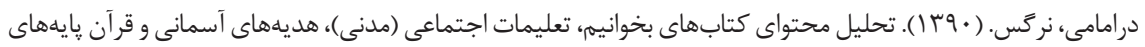

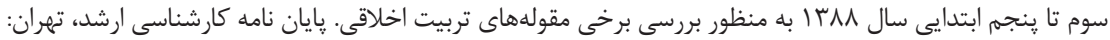
دانشخاه علامه طباطبايى.

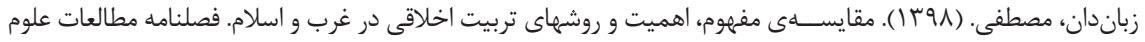

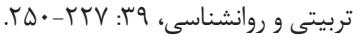

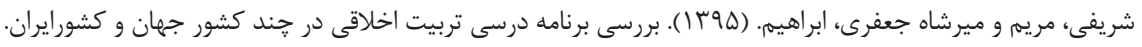

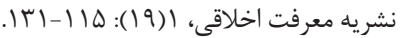

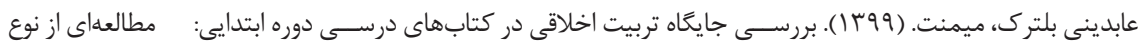

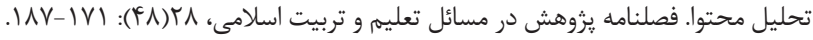

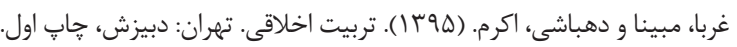

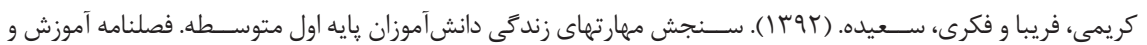

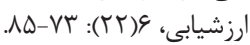

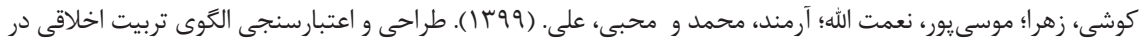

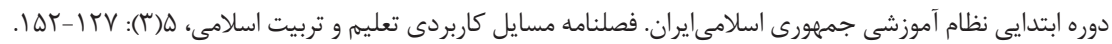

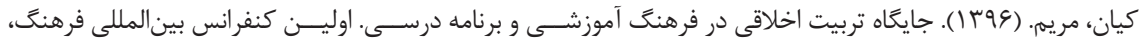

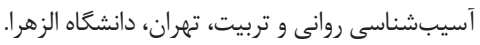

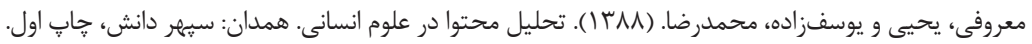




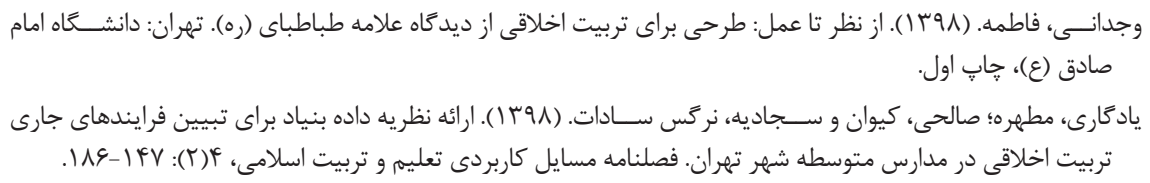

\section{REFERENCES}

Cheng, Ching-Hsue \& Lin, Yin. (2002). The Fuzzy Delphi Method is Derived from the Traditional Delphi Method and the Fuzzy set Theory. European Journal of Operational Research, 142:174186.

Fong, S.F., Cheng, P \& Por, F.B. (2013). Development of ICT Competency Standard Using the Delphi Technique. Procedia - Social and Behavioral Sciences, 10(3): 299 - 314.

Jainz, A. (2017). "The Re-emergence of Character Education in American Education Policy". American Journal of Educational Studies, 53: 239- 254.

Mullen, P. (2003). Delphi: Myths and Reality. Journal of Health Organisation and Management, 17(1): 37-52.

Neuman, L. (2006). Social Research Methods: Quantitative and Qualitative Approaches.Third Edition. London: Allyn and Bacon, 3: 404-405.

Okoli, C \& Pawlowski, S.D. (2004). The Delphi Method as a Research tool: an Example, Design Considerations and Applications. Information \& Management, 42 (1): 15-29.

Roy, T.K. \& Garai, A. (2012). Intuitionistic Fuzzy Delphi Method: More Realistic and Interactive Forecasting Tool. Notes on Intuitionistic Fuzzy Sets, 18(2)37-50 :.

Scalamovsky, A., Hartman, H \& Crane, D. (2007). Economics of Natural Resources and the Environment. Springer. ISBN 0-412-36330-5.

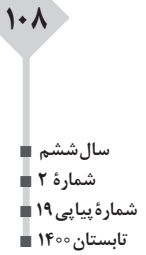

